\title{
Regional impacts of sustainable energy in western Finland
}

\section{Peura, Pekka}

2018-06-20

Peura , P , Haapanen , A , Reini , K \& Törmä , H 2018 , ' Regional impacts of sustainable energy in western Finland ' , Journal of Cleaner Production , vol. 187 , pp. 85-97 . https://doi.org/10.1016/j.jclepro.20

http://hdl.handle.net/10138/313477

https://doi.org/10.1016/j.jclepro.2018.03.194

cc_by_nc_nd

acceptedVersion

Downloaded from Helda, University of Helsinki institutional repository.

This is an electronic reprint of the original article.

This reprint may differ from the original in pagination and typographic detail.

Please cite the original version. 


\section{Accepted Manuscript}

REGIONAL IMPACTS OF SUSTAINABLE ENERGY IN WESTERN FINLAND

Pekka Peura, Ari Haapanen, Kaarina Reini, Hannu Törmä

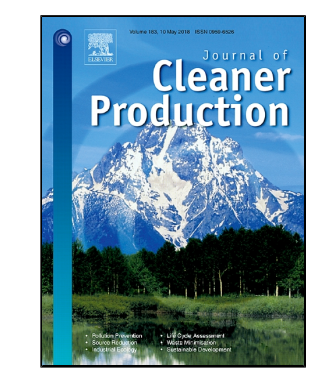

PII:

S0959-6526(18)30865-5

DOI:

10.1016/j.jclepro.2018.03.194

Reference:

JCLP 12452

To appear in:

Journal of Cleaner Production

Received Date:

19 December 2017

Revised Date:

10 February 2018

Accepted Date:

19 March 2018

Please cite this article as: Pekka Peura, Ari Haapanen, Kaarina Reini, Hannu Törmä, REGIONAL IMPACTS OF SUSTAINABLE ENERGY IN WESTERN FINLAND, Journal of Cleaner Production (2018), doi: 10.1016/j.jclepro.2018.03.194

This is a PDF file of an unedited manuscript that has been accepted for publication. As a service to our customers we are providing this early version of the manuscript. The manuscript will undergo copyediting, typesetting, and review of the resulting proof before it is published in its final form. Please note that during the production process errors may be discovered which could affect the content, and all legal disclaimers that apply to the journal pertain. 


\section{REgIONAL IMPACTS OF SUSTAINABLE ENERGY IN WESTERN FINLAND}

Pekka Peura*, Director, PhD; Corresponding author tel: +358294498206

email: pekka.peura@uva.fi

Ari Haapanen*, Project manager, MSc; Author

email: ari.haapanen@uva.fi

Kaarina Reini**, Researcher, PhD; Author

email: kaarina.reini@abo.fi

Hannu Törmä**, Professor, Docent; Author

email: hannu.torma@helsinki.fi

* Levón Institute, University of Vaasa; PB 700; 65101 Vaasa; Finland

** Ruralia Institute, University of Helsinki; Kampusranta 9; 60320 Seinäjoki; Finland

\section{Abstract}

The scope of this research is to make quantitative estimates of the potential economic and employment impacts of renewable energy self-sufficiency. The study aims to make generalizations on a regional, or even national level, and to give directions for future research. This paper analyses direct monetary values and employment impacts in two regions, in a theoretical situation where all energy is produced by renewables from the respective region.

Renewable energy, especially utilization of existing but presently unused resources, can play an important role in vitalizing regional economies, especially in rural areas. The money spent on fossil energy could be kept circulating in the regional economy. The amount spent on energy in the research areas was almost $€ 4,860$ per capita per year, totalling more than $€ 300 \mathrm{~m}$ annually. The existing data shows that there is the potential for self-sufficiency, or even surplus production. The results suggest that the regional economic impacts increase considerably if the region is self-sufficient in raw materials, including intermediates. On a larger scale, e.g., nationally, the loss of jobs in the fossil energy industry and the eventual variations within economies potentially based on renewable energy, will affect the overall impacts.

There is at present insufficient scientific literature, knowledge or quantitative data for analysing these impacts thoroughly. This paper contributes to filling this gap.

\section{Highlights}

- In rural areas, $100 \%$ renewable energy can potentially be produced.

- Renewable energy can replace fossil fuels and keep money within the region.

- Renewable energy can contribute up to almost $€ 5,000$ per capita to regional economies.

- Employment, vitality and local business add value to the regional economy.

\section{Key words}

Sustainable energy, regional economy, regional value added, Renewable Energy Sources (RES) 


\section{Introduction}

The concept of sustainable energy (SE) directly follows from the concept of sustainable development, which has more than three hundred definitions within the context of environmental management, (e.g., IUCN, 1980; WCED, 1987; Markandya et al., 2002; Johnston et al., 2007; Chichilnisky, 2011; Peura et al., 2014). A plethora of definitions of SE can also be found in the recent literature. Based on a wide review, the SE concept was redefined to include the following (Peura, 2013a;b):

1 RUE (rational use of energy, saving, efficiency)

2 RES (renewable energy sources)

3 Integration of RUE and RES

4 Sustainability management

There are a number of technologies for RUE and RES that can be implemented separately or in combination. The integration of these is the key for complete solutions. With different combinations of techniques and regional RES, it is possible to create solutions with different degrees of energy self-sufficiency. The use of RES depends on the carrying capacity, and cannot be increased limitlessly. Sustainability management is necessary to avoid adverse impacts and careless use of RES. There is always a danger that SE projects may become a type of ecological colonialism, where a pattern of robbery will take over (Peura, 2013a;b), and principles of maximal economic gain and carelessness regarding the environment will be applied while producing RES in the name of sustainability (Blarke, 2008; Moriarty and Honnery, 2009).

SE has become one of the key concepts in reforming the energy sector in the EU and worldwide. The production of energy has caused major impacts on the environment, leading to the following statements. "Renewable energy is one of the most efficient ways to achieve sustainable development" (Goldemberg, 2007). "One of the main tasks in this century (...) will be to manage a transition process towards a sustainable energy system" (Haas et al., 2008).

The potential regional economic and employment impacts are among the most powerful drivers for SE. For instance, it is repeatedly claimed that RES generates more jobs than conventional energy (Sastresa et al., 2010). The claim that "... real effects have stayed on a non-measurable level" (Hoffmann, 2009), has also become a widely discussed issue, with estimates having a "... high level of dispersion in the ratios and the order of magnitude" (Sastresa et al., 2010).

We know that the business case for RES, including investments (Peura and Hyttinen, 2011; Masini and Menichetti, 2012) and benefits beyond business profitability, can be significant. The regional value added (monetary aspects, reduction of costs, increase of purchasing power, creation of jobs, tax income, social, ecological and ethical aspects and improved vitality) would be remarkable if all the money which currently flows out remained within the region (Hillebrand et al., 2006; Lehr et al., 2008; Moreno and López, 2008; Thornley et al., 2008; Blanco and Rodrigues, 2009; Hoffmann, 2009; del Río and Burguillo, 2009; Openshaw, 2010; Sastresa et al., 2010; Dalton and Lewis, 2011; Masini and Menichetti, 2012).

However, the scientific literature on the socio-economic impacts of SE mainly concentrates on costs and employment, for instance methods for analysing 
employment within some branches or for separate technologies (and in some cases their value chains), and includes jobs created during the construction phase as well as the operation and maintenance of the studied production plants (for reviews, see Ortega et al., 2015; Connolly et al., 2016; Többen, 2017) or in lowcarbon technologies, including RES (Markandya et al., 2017).

These are mainly ex ante assessments of potential impacts, based to different extents on existing data and scenarios for future systems. Often, the results are confusingly contradictory, depending on the settings, approach, scale and regional content of each study. For instance, the job creation impact in the operation and management phase has been proven, while the impact in the construction phase has not been as large as predicted in Italy (Cai et al., 2017). Another study showed that renewable energy generation has a positive impact on economic growth at the regional level in Italy (Magnani and Vaona, 2013).

The methodology has not been established, and there are very few analyses that cover potential regional economic impacts of RES self-sufficiency. It is rather simple to "count euros" for certain power plants or a combination of plants, but there is clearly a gap in estimating economic impacts for a whole region and its economy, and for different branches in a $100 \%$ RES regional system.

The physical prerequisites for SE exist. "There is a consensus that the energy system will need to change, but ... a lot of uncertainty ..." of "... how" (Connolly et al., 2016). A shift towards SE and away from fossil fuels will presumably be on the global agenda in the near future. However, there are institutional and other barriers slowing the process (Peura, 2013a;b). The barriers are non-technical challenges, rather than technical issues (McCormick and Kåberger, 2007). Therefore, all analyses are based on different potential future scenarios of, e.g., $100 \%$ renewable energy systems. It is crucial that the main principles of SE are followed, and especially that the solution is sustainable.

The scope of this research was to estimate the potential economic and employment impacts of the renewable energy self-sufficiency that could be put into practice in the target areas. The paper aims to make generalizations on a regional level, with the potential for also applying the approach nationally and internationally. It also aims to give directions for future research.

Improved knowledge and understanding concerning the potential regional economic and employment impacts of sustainable energy is important because:

- These impacts are among the main drivers for implementing sustainable energy (SE),

- The scientific literature on them is sparse, and a research methodology has not been established,

- Sustainable energy has become one of the main topics in the ongoing transition of the whole energy sector.

The paper has been organised as follows: Section 2 highlights the research design and study area, section 3 presents the methodology and section 4 collates the results. A discussion is presented in section 5 , and conclusions are given in section 6. 


\section{Research Design and Study Areas}

\subsection{Research Design}

The scope of the research was to make quantitative estimates of the potential economic and employment impacts of energy self-sufficiency (100\% RES production, all sources from within the region, some comparisons with $125 \%$ and $150 \%$ self-sufficiency) at three regional levels, as follows.

- Villages: the small areas in the Energy Village project.

- Municipalities: where the Energy Villages are located.

- Regions: the areas surrounding two Energy Villages (Jepua and Perho).

All initial data about energy balances were gathered from the Energy Villages and their municipalities and regions, including official figures for electricity consumption, calculated heat demand and transport fuel, accompanied by the calculated bioenergy potentials and projected wind energy potentials.

The main potential solutions in these areas have been the production of biogas, the use of CHP (combined heat and power generation) via combustion of mainly wood material, and wind power. In Jepua village, there is already a biogas plant in operation, and there is considerable experience in the combustion of wood (logs, chips and pellets) in Finland. There are also a number of wind farms at the planning stage and undergoing permit procedures, in the research areas. These three technical solutions were selected, firstly, to avoid an overcomplicated cloud of parameters in the calculation, and secondly, because they are the potential solutions most likely to be implemented in the very near future.

The regional economic and employment impacts were estimated in two ways.

1. In the villages, municipalities and regions, the impacts were calculated for an imaginary technical (biogas, CHP, wind) composition of $100 \%$ RES production, based on the initial data from separate supply chains for biogas, CHP and wind power production. Wind energy was taken into account whenever there was insufficient bioenergy potential for producing $100 \%$ RES self-sufficiency.

2. The regions were modelled using the RegFin regional economic model with the initial data from Jepua and Perho Energy Villages based on 100\%, $125 \%$ and $150 \%$ RES production, where $125 \%$ and $150 \%$ signify the ability to sell energy outward from the village. The same value chain data as above were used here.

\subsection{Study Areas}

The research areas were selected from the Energy Village project. The main criteria for selection were the availability and quality of the initial data and the suitability of the villages and regions for the RegFin research model. The study areas are shown in Fig. 1 and the main regional characteristics have been collated in Tables 1 and 2 .

The main targets for studying the regional economic and employment impacts of $100 \%$ renewable energy self-sufficiency were the six small areas, here called the "Energy Villages", shown in Fig. Each Energy Village consists of a small community and its surrounding cultivation grounds, forests and other areas, separately defined for each village. The borders are defined separately for each village, mainly based on the ownership of estates. Theoretically, neighbouring villages should border each other. Jepua and Perho villages have been shown as examples in Appendix 1. 
Because large areas with high potential bioenergy sources remained outside the defined village borders, the municipalities of the villages were also used as comparison material in the calculations. In Jakobstad and Kaustinen regions, data were also compiled for the whole region.
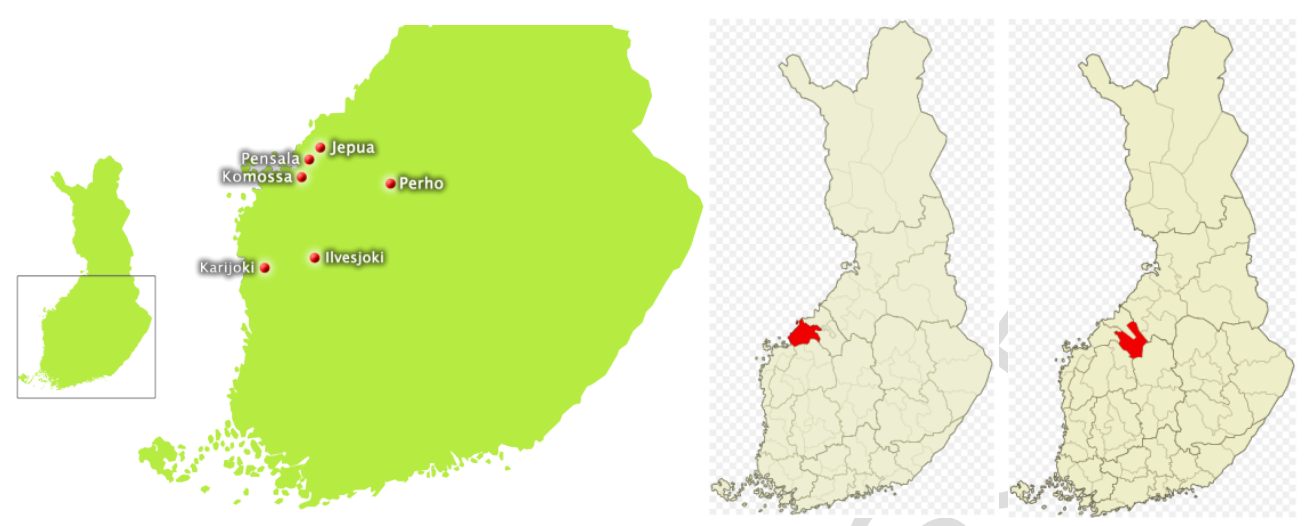

Figure 1. Energy Villages in the regions of Ostrobothnia, South Ostrobothnia, Central Ostrobothnia and Northern Ostrobothnia, and the regions of Jakobstad (middle) and Kaustinen (right).

Table 1. Characteristics of the research areas: Kaustinen and Jakobstad regions, their municipalities and Energy Villages, and the municipalities of Vörå, Karijoki and Jalasjärvi together with their Energy Villages.

\begin{tabular}{|c|c|c|c|c|c|c|}
\hline \multirow{2}{*}{$\begin{array}{l}\text { Region } \\
\text { Municipality } \\
\text { Village }\end{array}$} & \multirow{2}{*}{$\begin{array}{c}\text { Population } \\
1000\end{array}$} & \multirow{2}{*}{$\begin{array}{l}\text { Land area } \\
\qquad \mathbf{k m}^{2}\end{array}$} & \multicolumn{3}{|c|}{ Economic structure; \% } & \multirow{2}{*}{$\begin{array}{c}\text { Un- } \\
\text { employed } \\
\%\end{array}$} \\
\hline & & & $\begin{array}{c}\text { Primary } \\
\text { production }\end{array}$ & Industry & Service & \\
\hline Kaustinen & 16,1 & 3261.6 & 25.6 & 20.5 & 52.1 & \\
\hline Kaustinen & 4.29 & 361.1 & 20.7 & 20.4 & 57 & 6.2 \\
\hline Halsua & 1.25 & 428.4 & 33.8 & 23.5 & 39.1 & 10.6 \\
\hline Lestijarvi & 0.84 & 559.1 & 50.7 & 11.3 & 36.3 & 7.2 \\
\hline Toholampi & 3.43 & 616.9 & 26.8 & 18.7 & 53 & 7.7 \\
\hline Veteli & 3.38 & 520.9 & 26.6 & 21.7 & 50 & 7.5 \\
\hline Perho & 2.92 & 775.2 & 20 & 23 & 55.8 & 11.8 \\
\hline Perho & 1.42 & 45.4 & & & & \\
\hline Jakobstad & 49.8 & 4504.1 & 11.1 & 37.3 & 50.4 & \\
\hline Jakobstad & 19.68 & 396.3 & 1 & 35.3 & 63.1 & 8.5 \\
\hline Pedersore & 10.94 & 826.1 & 13.2 & 40.8 & 45 & 3.9 \\
\hline Kronoby & 6.67 & 752.7 & 13.9 & 38.1 & 46.7 & 4.4 \\
\hline Larsmo & 4.97 & 853.6 & 3.8 & 38.4 & 55.9 & 3.5 \\
\hline Nykarleby & 7.53 & 1675.4 & 20 & 32.8 & 45.5 & 3.9 \\
\hline Jepua & 1.18 & 126.9 & & & & \\
\hline Pensala & 0.37 & 39.4 & & & & \\
\hline Vörå & 6.68 & 1500 & 15.5 & 32.9 & 50.3 & 3.6 \\
\hline Komossa & 0.10 & 27.5 & & & & \\
\hline Karijoki & 1.51 & 186.6 & 27.3 & 32.8 & 38.5 & 8.9 \\
\hline Karijoki & 0.83 & 37.1 & & & & \\
\hline Jalasjärvi & 8.07 & 830.5 & 19.6 & 26.5 & 52.2 & 9.2 \\
\hline Ilvesjoki & 0.53 & 90.5 & & & & \\
\hline Finland & 5426.7 & 303891 & 3.5 & 22.1 & 73.1 & 9.8 \\
\hline
\end{tabular}


Table 2. Economic characteristics of the Jakobstad and Kaustinen regions and of Finland (GDP = gross domestic production).

\begin{tabular}{|l|c|c|c|}
\hline & $\begin{array}{c}\text { Jakobstad } \\
\text { Region }\end{array}$ & Finland & $\begin{array}{c}\text { Kaustinen } \\
\text { Region }\end{array}$ \\
\hline GDP/pers, 1000€ & 33.8 & 33.3 & 18.9 \\
\hline GDP/pers, index & 101.3 & 100 & 56.7 \\
\hline GDP, M€ & 1670 & 178796 & 309 \\
\hline \hline
\end{tabular}

Jepua and Perho Energy Villages were used separately to provide basic data in modelling the regional economic and employment impacts of sustainable energy in the regions of Jakobstad and Kaustinen (Fig.) respectively. Their main regional characteristics are given in Table 2.

Summarizing, this research considered a total population of 82,000 inhabitants and a land area of ca $10,300 \mathrm{~km}^{2}$. In the Energy Villages, the corresponding figures were 4,330 inhabitants and $367 \mathrm{~km}^{2}$.

\section{Research Methods and Data}

\subsection{Energy Balances in the Energy Villages and Regions}

The energy balances by village and region were defined based on calculations of energy demand and RES potential, both briefly described below.

\subsubsection{Energy Demand}

Energy demand figures were mainly collected from, or calculated according to, published statistics and interviews. The methods used are listed in Table 3.

Table 3. Summary of the methods used for obtaining energy demand figures.

\begin{tabular}{|l|l|l|}
\hline Demand & \multicolumn{1}{|c|}{ Method } & \multicolumn{1}{c|}{ Source } \\
\hline Electricity & Official statistics & $\begin{array}{l}\text { Statistics Finland (2013) } \\
\text { www.energy.fi }\end{array}$ \\
\hline Heating & $\begin{array}{l}\text { Interviews; } \\
\text { Calculation based on building } \\
\text { areas and average heat demand } \\
\text { according to statistics }\end{array}$ & $\begin{array}{l}\text { Municipalities } \\
\text { Statistics Finland (2013) }\end{array}$ \\
\hline $\begin{array}{l}\text { Transport fuel } \\
\text { (light traffic: passenger cars } \\
\text { and vans } \\
\text { heavy traffic: trucks and } \\
\text { buses) }\end{array}$ & $\begin{array}{l}\text { Average distance by vehicle and } \\
\text { average consumption multiplied by } \\
\text { the number of vehicles; } \\
\text { Statistics by area } \\
\text { Separately: light and heavy traffic } \\
\text { and farming machines }\end{array}$ & $\begin{array}{l}\text { Municipalities } \\
\text { Statistics Finland (2013) } \\
\text { Interviews }\end{array}$ \\
\hline \hline
\end{tabular}

Energy demand consists of the use of electricity and heating energy, and also includes transport fuels. Electricity use data have been taken from official statistics, originating from metered data and reports by energy utilities. These figures represent total actual use of electricity in a given area, and they have been previously published (www.energia.fi). 
The use of heating energy includes all buildings, and has been calculated by multiplying the areas of the buildings with the estimated average consumption per square metre $\left(141 \mathrm{kWh} / \mathrm{m}^{2}\right)$. These figures have been taken from official statistics. For industry, the energy demand figures include all electricity use, but the process heat demand is not known.

Consumption of transport fuel was calculated as a simple multiplication of vehicle and machine numbers, average distances driven or hours used and average consumption, calculated separately for different regional units and different vehicle categories.

- Regional units: villages, municipalities and the two regions.

- Numbers of vehicles by category: light traffic including personal vehicles etc., heavy traffic including buses, trucks etc. and farm machinery.

The average figures for consumption and distance or use per year were as follows:

$\begin{array}{lcc} & \begin{array}{r}\text { Consumption } \\ \text { litres/100 km } \\ \text { * litres/hectare/year }\end{array} & \begin{array}{c}\text { Distance } \\ \mathrm{km} / \text { year }\end{array} \\ \text { Passenger cars } & 7.4 & 17,000 \\ \text { Vans } & 10 & 20,000 \\ \text { Trucks } & 32.1 & 50,000 \\ \text { Buses } & 30 & 65,000 \\ \text { Farming machines } & * 140 & \end{array}$

The numbers of vehicles in each region by category were obtained from municipalities for villages and municipalities, and from national statistics for regions. The average consumption and the distances and hours of use were taken from national statistics.

\subsubsection{Bioenergy and Wind Energy Potential Metrics}

There are several definitions of RE supplies in the literature, adequately summarized by Verbruggen et al. (2010) and Doukas et al. (2007). The supply, from several types of sources, is "... obtained from the continuing or repetitive currents of energy occurring in the natural environment and includes non-carbon technologies such as solar energy, hydropower, wind, tide and waves and geothermal heat, as well as carbon-neutral technologies such as biomass" (Doukas et al., 2007). These sources have been described in more detail by, e.g., Verbruggen et al. (2010) and Ragwitz et al. (2005).

Renewable energy also includes wind, solar, hydropower and geothermal energy. There are however no reliable statistics for these sources which could be compared with, or presented in the same way as, the bioenergy potential, and therefore these forms of RES have been excluded from the calculations. Because they are in principle inexhaustible, especially over small areas, they have been included in some regional analyses and in the discussion, not as a "total regional potential" but as examples of the type "how many wind turbines would cover a certain energy demand", etc. Other forms of RES have not been considered because they are either unavailable in Finland or the technology is still underdeveloped for wider utilization.

In this study, only bioenergy and wind power have been taken into account. These sources exist in the study areas, there are industries refining some of the sources, there is infrastructure for utilizing them, (e.g., in forestry), their energy content can reliably be measured, and there is practically no social resistance against taking 
advantage of them. The figures for the energy content of each RES material were calculated or collected separately from within the defined borders for each region, municipality and Energy Village. The methods for obtaining the quantities of RES materials available are described briefly below, and shown in Table 4.

Table 4. Summary of the methods for attaining bioenergy supplies.

\begin{tabular}{|l|l|l|}
\hline Fraction & \multicolumn{1}{|c|}{ Method } & \multicolumn{1}{c|}{ Source } \\
\hline Manure & $\begin{array}{l}\text { Number of domestic animals; } \\
\text { different species and sub-groups }\end{array}$ & $\begin{array}{l}\text { Municipal officers } \\
\text { Ministry of Agriculture and Forestry }\end{array}$ \\
\hline Sludge & Official statistics & $\begin{array}{l}\text { Municipalities; Environment } \\
\text { administration }\end{array}$ \\
\hline $\begin{array}{l}\text { Biomass from } \\
\text { cultivation grounds }\end{array}$ & $\begin{array}{l}\text { Reed canary grass crop (tons/ha) } \\
\text { potential from fallowed areas }\end{array}$ & $\begin{array}{l}\text { Municipalities } \\
\text { Ministry of Agriculture and Forestry }\end{array}$ \\
\hline Wood & $\begin{array}{l}\text { Logging residues only; } \\
\text { Actual data from loggings }\end{array}$ & Regional Forestry Centres \\
\hline $\begin{array}{l}\text { Straw and other } \\
\text { cultivation residues }\end{array}$ & $\begin{array}{l}\text { Cultivated areas; Specific harvest } \\
\text { and energy content for species }\end{array}$ & $\begin{array}{l}\text { Municipalities } \\
\text { Ministry of Agriculture and Forestry }\end{array}$ \\
\hline Municipal biowaste & Official statistics & Environment administration \\
\hline \hline
\end{tabular}

All quantities were transformed into energy content units by multiplication with generally available and commonly used specific values, (e.g., Turunen, 1999; Alakangas, 2000; Uusi-Penttilä, 2004; Finbio, 2005; Doukas et al., 2007).

In the Energy Village project, the research targets were villages or subregions of municipalities. Because most of the statistics had been collected by municipalities, the material was mainly obtained via personal contacts in these areas. All the villages were visited, and the interviews took place on a face-to-face basis. All the people contacted fell into the following categories: municipal officers (technical directors, environmental, rural and business managers), personnel from the regional energy utilities or from development organizations and enterprises.

The biogas potential was calculated based on the share of total and volatile solids (TS, VS) and material-specific gas production (Turunen, 1999; Uusi-Penttilä, 2004). All quantities were then transformed into energy content units by multiplication with generally available and commonly used specific values (Alakangas, 2000; UusiPenttilä, 2004; Finbio, 2005).

This compilation of bioenergy metrics, based on official statistics and relevant specific figures and taking into account geographical features, corresponds to the harmonization methods proposed for the EU (Doukas et al., 2007). In the literature, this method of using official statistics as a starting point, multiplying by specific values and taking geographical characteristics into account, seems to be typical; for example, for the potential of global field biomass (Hakala et al., 2009), global bioenergy (Fischer and Schrattenholzer, 2001; Smeets et al., 2007) global sustainable biomass energy (Ladanai and Vinterbäck, 2009; Ceciliano, 2010), global bioenergy from forestry (Smeets and Faaij, 2007) and overall RES globally (Resch et al., 2008). In summary, the methods used in our studies are based on the same principles as in the mainstream of the scientific literature.

Wind energy potential estimates in this study were based on the projected wind farm projects in each research area. 


\subsection{Economic Value of Energy and the Value Chain}

The value of energy was calculated for all regional categories according to the following current energy prices:

$\begin{array}{ll}\text { Electricity: } & 0.12522 € / \mathrm{kWh} \\ \text { Gasoline and diesel: } & 1.575 € / \mathrm{I} \\ \text { Oil: } & 1.13 € / \mathrm{I}\end{array}$

The price for heating was calculated by multiplying the unit price of the fuel and the total area per building category by municipality. The total building areas by municipality were divided into different building categories using the national average proportions, since no specific data were available concerning these categories in the municipalities. Each heating method uses a specific fuel, and each fuel has a different price.

It is presupposed that all the money presently spent on energy will be used for energy also in the future. Therefore, the whole sum of money (per regional category) was split between the three potential RES solutions: biogas, CHP and wind power. The shares of energy presumed to be produced by these three solutions were different for each region, depending on the characteristics of the region. The starting point was to maximize the use of bioenergy, which gives the best value for the regions, and for which investments would be achievable by smaller regional actors.

The pre-existing data about the division of money flow along the three value chains of biogas, CHP and wind power, allowed a rough and indicative estimate of the money flow for the whole RES-based production of energy, and how it might be split into different branches within the regions.

\subsection{CGE RegFin Simulation Model}

The analysis was performed using the CGE (Computable General Equilibrium) RegFin regional simulation model developed at the Ruralia Institute of the University of Helsinki. Models belonging to the CGE category are seen as the best tools for quantitative impact assessment of widespread changes in economic conditions. They were developed to overcome weaknesses in the older linear evaluation techniques, such as input-output models, which tend to overestimate impacts. The scenario results reflect the influence of both changes in relative prices and output or income. The total impact from a change in economic conditions includes direct impact on the core sector under analysis, indirect impacts downstream and upstream in the value chain for those sectors that serve the core sector and induced impacts via income generation, and private and public consumption. Indirect and induced impacts are called multiplier impacts. A more thorough introduction to CGE models and their use can be found, e.g., in a handbook of CGE modelling (Dixon and Jorgensen, 2012).

The regional multisectoral and inter-regional CGE models are known as the RegFin or "Regional model for Finland". In numerical simulation bottom-up models, the regional impacts of a change in economic conditions are determined for all regions simultaneously. National macro results for economic growth, employment, labour and capital income, private consumption, tax revenues, public consumption and trade etc., are calculated alongside the regional results. CGE RegFin models are available both as comparative-static and recursive-dynamic versions (Törmä et al., 2015). Descriptions of the comparative-static model were presented by Törmä (2008), Rutherford and Törmä (2010), Törmä et al. (2010) and Törmä and 
Zawalinska (2010; 2011). The comparative-static version of the model was used in this study. CGE RegFin models have been used for Finland in over 50 studies. Twin models with various applications have been created for the whole European Union and its member countries (Törmä and Zawalinska, 2010; 2011; Metsäranta, 2012). The structure of the model is described in Appendix 2.

In the case of a totally self-sufficient raw material chain, all intermediates are bought from inside the region. This represents a closed regional economy. A totally self-sufficient raw material chain was implemented in the model by increasing the supply of local intermediates to some extent, corresponding to the initial demand. As a consequence, the prices of local intermediates decrease, and their competitiveness is improved. In addition, transportation costs will fall. The use of intermediates organized in this way is focused on the region. The actual situation is somewhere between an open and closed raw material chain.

The three renewable energy production types were disaggregated from the larger sectors of electricity, gas and water. It was necessary to estimate the cost and sales structures of the three new production types, which deviate from those of the core sectors. Additional data were gathered from previous research, the literature, the planning documents of the plants and by interviewing the CEOs or owners of the plants (for details, please see Reini et al., 2014).

\section{Results}

\subsection{Energy Balances and Economies in the Research Areas}

\subsubsection{Energy Balances in the Research Areas}

An energy balance consists of the consumption and the potential of renewable energy sources within each area, i.e., village, municipality and region. The energy consumption figures, including all energy used for electricity, heating and transport fuels, are collated in Table 5. The RES potentials are presented in Table 6. Energy balances are then expressed as the sum of the total energy consumption and total RES potential by research area. These are illustrated in Fig. 2 .

Energy consumption clearly reflects the regional characteristics, depending, e.g., on the population and economic structure of each area. For instance, Komossa and Pensala are small villages in agricultural surroundings, while other villages have larger populations and have industries within their areas. In Perho, the Energy Village accounts for about half of the energy consumption of the whole municipality, while in Karijoki, the consumption represents more than half.

The city of Jakobstad has a great deal of large-scale industry in its area, and it consumes some $55 \%$ of all the energy consumed in the region. The electricity and heating energy consumption within the municipality, and within the region, are especially high. The whole Kaustinen region, like the municipalities of Jalasjärvi, Vörå and Karijoki, has a high share of primary production in its economic structure, while the Jakobstad region is highly industrialized and has many SME industries.

The balances imply the ability to produce all energy by RES in the studied regions. However, some municipalities and the village of Karijoki lack this potential ability. It is typical that consumption is concentrated in population centres and within industry, while RES potential is more scattered, for example depending on the locations of areas of forest or cultivated grounds. As an example, in Karijoki municipality, the RES potential is three times higher than the energy demand, although in the main population centre the demand is larger than the potential. 
Table 5. Energy consumption (GWh/a) in the research areas.

\begin{tabular}{|c|c|c|c|c|c|c|}
\hline $\begin{array}{l}\text { Region } \\
\text { Municipality } \\
\text { Village }\end{array}$ & Electricity & Heat & Heavy & $\begin{array}{l}\text { anspor } \\
\text { Light }\end{array}$ & $\begin{array}{l}\text { Agri- } \\
\text { culture }\end{array}$ & TOTAL \\
\hline Kaustinen & 169 & 193 & 145 & 124 & 43 & 674 \\
\hline Kaustinen & 52 & 56 & 38 & 34 & 8.6 & 189 \\
\hline Halsua & 11 & 16 & 9.7 & 11 & 4.6 & 52 \\
\hline Lestijarvi & 12 & 11 & 7.0 & 5.9 & 2.8 & 38 \\
\hline Toholampi & 40 & 43 & 31 & 24 & 9.5 & 147 \\
\hline Veteli & 31 & 40 & 33 & 28 & 9.5 & 141 \\
\hline Perho & 23 & 29 & 26 & 21 & 8.1 & 107 \\
\hline Perho & 14 & 11 & 13 & 10 & 1.3 & 49 \\
\hline Jakobstad & 1252 & 530 & 281 & 321 & 51 & 2436 \\
\hline Jakobstad & 887 & 241 & 84 & 123 & 1.2 & 1336 \\
\hline Pedersore & 107 & 102 & 74 & 72 & 20 & 374 \\
\hline Kronoby & 121 & 80 & 50 & 46 & 15 & 312 \\
\hline Larsmo & 30 & 30 & 14 & 29 & 1.0 & 104 \\
\hline Nykarleby & 107 & 78 & 59 & 51 & 14 & 308 \\
\hline Jepua & 25 & 23 & 22 & 10 & 1.2 & 81 \\
\hline Pensala & 3.8 & 3.6 & 2.0 & 2.8 & 1.2 & 13 \\
\hline Vörå & 70 & 44 & 49 & 45 & 22 & 230 \\
\hline Komossa & 1.0 & 1.2 & 0.9 & 0.9 & 0.9 & 4.9 \\
\hline Karijoki & 15 & 20 & 16 & 10 & 8.1 & 69 \\
\hline Karijoki & 6.5 & 10 & 10 & 7.1 & 1.5 & 35 \\
\hline Jalasjärvi & 81 & 99 & 70 & 53 & 8.6 & 311 \\
\hline Ilvesjoki & 4.6 & 6.7 & 4.6 & 4.9 & 1.4 & 22 \\
\hline
\end{tabular}

Table 6. Bioenergy (allocated by biogas and CHP production) and wind power potential (GWh/a) in the research areas.

\begin{tabular}{lccrr}
\hline \hline $\begin{array}{l}\text { Region } \\
\text { Municipality } \\
\text { Village }\end{array}$ & Biogas & CHP & Wind & TOTAL \\
Kaustinen & \multicolumn{1}{c}{ 195 } & $\mathbf{5 3 8}$ & $\mathbf{1 5 7 3}$ & $\mathbf{2 3 0 6}$ \\
Kaustinen & 38 & 83 & & 121 \\
Halsua & 18 & 50 & & 67 \\
Lestijarvi & 12 & 82 & 736 & 830 \\
Toholampi & 51 & 113 & 721 & 885 \\
Veteli & 43 & 101 & & 144 \\
Perho & 35 & 108 & 115 & 258 \\
$\quad$ Perho & 9.6 & 11 & 57 & 78 \\
\hline Jakobstad & $\mathbf{2 0 0}$ & $\mathbf{6 5 4}$ & $\mathbf{2 0 2 7}$ & $\mathbf{2 8 8 1}$ \\
Jakobstad & 3.8 & 35 & 89 & 128 \\
Pedersore & 70 & 210 & 332 & 612 \\
Kronoby & 64 & 171 & 41 & 276 \\
Larsmo & 3.4 & 32 & 3.2 & 39 \\
Nykarleby & 59 & 205 & 1562 & 1826 \\
$\quad$ Jepua & 18 & 35 & 28 & 81 \\
Pensala & 15 & 3.7 & 270 & 288 \\
\hline Vörå & 63 & 194 & 52 & 309 \\
Komossa & 3.5 & 10 & 1.6 & 15 \\
\hline Karijoki & 35 & 55 & 114 & 204 \\
Karijoki & 1.8 & 15 & 8.5 & 25 \\
\hline Jalasjärvi & 38 & 127 & 172 & 336 \\
$\quad$ Ilvesjoki & 6.4 & 19 & 172 & 197 \\
\hline \hline
\end{tabular}



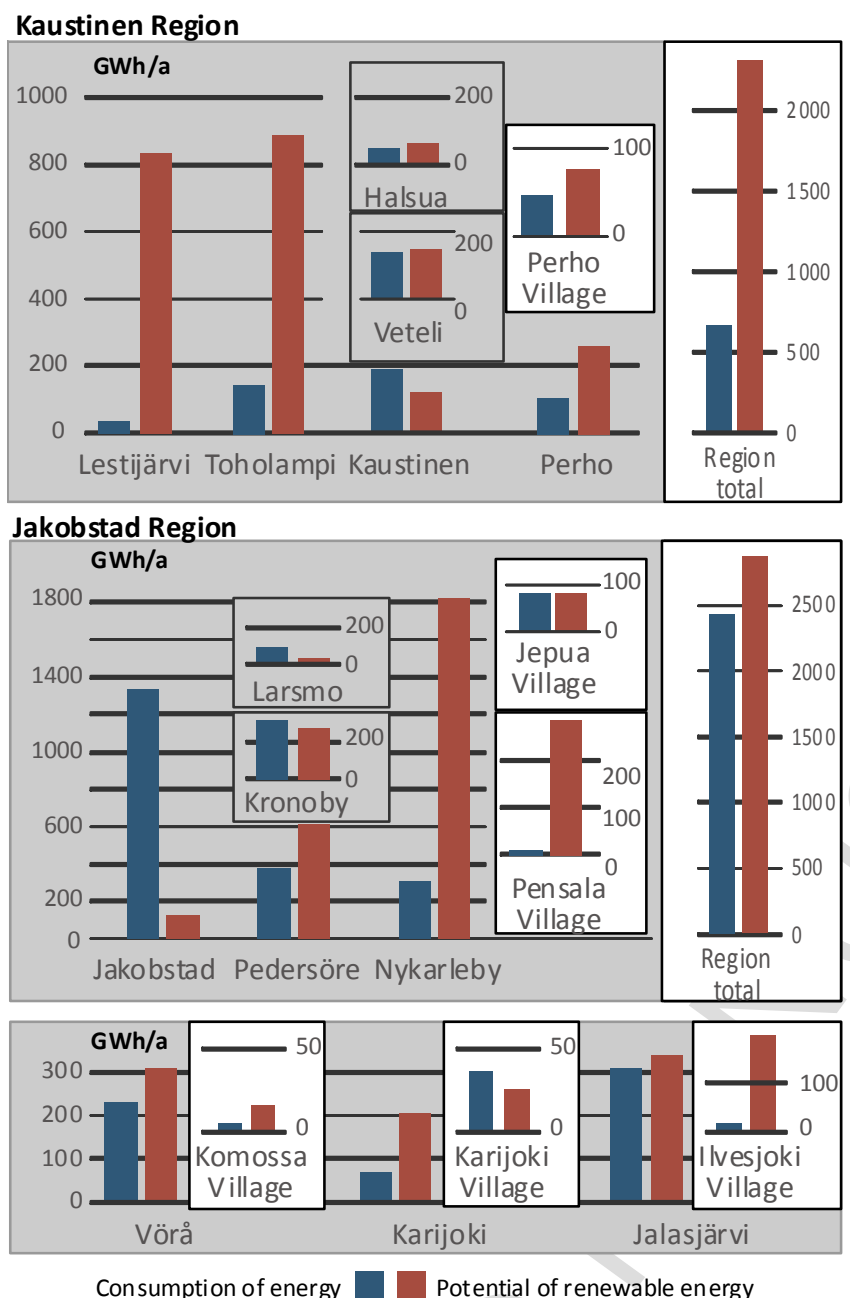

Figure 2. Energy balance (consumption-potential, GWh/a) in the research areas.

The whole Kaustinen region could potentially produce three times more energy than it consumes. However, in Kaustinen municipality, the demand exceeds the potential. In Jakobstad region the city of Jakobstad consumes half of all the energy, and it would have to depend on the surrounding region if it was to obtain all its energy from RES.

\subsubsection{Economic Value of Energy and the Value Chain}

The theoretical allocation of RES resources in order to produce $100 \%$ RES selfsufficiency by region is shown in Table 7. As shown in the table, only a part of the available RES was used for the allocation. In the Kaustinen region, especially, almost two thirds of the potential resources were omitted. This was done in order to make the calculation as simple as possible, to gain as good an understanding as possible of the economic potential, and because only a rough estimate is intended here.

In the Kaustinen region, $100 \%$ RES self-sufficiency would only require a minor share of wind power in most cases. In Perho municipality there are wind power units under construction, and a small part of their potential energy yield was used to even out the total use of RES. This was necessary, as the bioenergy potential in Kaustinen municipality would not cover the municipality's demand. 
The situation was very different in the Jakobstad region. The highly industrialized city of Jakobstad consumes a great deal of energy, and a considerable amount of wind energy potential had to be used for the allocation in order to achieve $100 \%$ RES self-sufficiency in the whole region. In the Jakobstad region most of the RES potential, including bioenergy and wind power, would be used.

Table 7. Allocation of the use of RES potential for achieving $100 \%$ regional RES selfsufficiency in the research areas (GWh/a).

\begin{tabular}{|c|c|c|c|c|c|c|}
\hline $\begin{array}{l}\text { Region } \\
\text { Municipality } \\
\text { Village }\end{array}$ & Consumption & Biogas & CHP & Wind & $\begin{array}{c}\text { Total } \\
\text { RES use }\end{array}$ & $\begin{array}{c}\text { Balance } \\
\text { with RES }\end{array}$ \\
\hline Kaustinen & 674 & 195 & 411 & 68 & 674 & 0 \\
\hline Kaustinen & 189 & 38 & 83 & & 121 & -68 \\
\hline Halsua & 52 & 18 & 34 & & 52 & 0 \\
\hline Lestijarvi & 38 & 11 & 27 & & 38 & 0 \\
\hline Toholampi & 147 & 51 & 96 & & 147 & 0 \\
\hline Veteli & 141 & 43 & 98 & & 141 & 0 \\
\hline Perho & 107 & 35 & 72 & 68 & 175 & 68 \\
\hline Perho & 49 & 9.6 & 11 & 28 & 49 & 0 \\
\hline Jakobstad & 2436 & 200 & 654 & 1582 & 2436 & 0 \\
\hline Jakobstad & 1336 & 3.8 & 35 & 89 & 128 & -1209 \\
\hline Pedersore & 374 & 70 & 210 & 332 & 612 & 238 \\
\hline Kronoby & 312 & 64 & 171 & 41 & 276 & -36 \\
\hline Larsmo & 104 & 3.4 & 32 & 3.2 & 39 & -66 \\
\hline Nykarleby & 308 & 59 & 205 & 1116 & 1380 & 1072 \\
\hline Jepua & 81 & 18 & 35 & 28 & 81 & 0 \\
\hline Pensala & 13 & 14 & 0 & & 14 & 1.1 \\
\hline Vörå & 230 & 63 & 167 & & 230 & 0 \\
\hline Komossa & 4.9 & 3.5 & 1.4 & & 4.9 & 0 \\
\hline Karijoki & 69 & 35 & 34 & & 69 & 0 \\
\hline Karijoki & 35 & 1.8 & 15 & 8.5 & 25 & -10 \\
\hline Jalasjärvi & 311 & 38 & 126 & 147 & 311 & 0 \\
\hline Ilvesjoki & 22 & 6.4 & 15 & 0 & 22 & 0 \\
\hline
\end{tabular}

The costs of energy in the research areas are shown in Table 8, according to consumption categories. Table 9 presents the value of $100 \%$ RES energy production allocated by RES energy categories. Finally, Table 10 summarizes the distribution of the corresponding money flows along the value chain, here represented by different branches. In the Kaustinen region, the total annual value of energy is more than $€ 74 \mathrm{~m}$, while in the Jakobstad region the value is nearly $€ 230 \mathrm{~m}$. The allocation of RES resources shows that in the Kaustinen region, with its primary production base, a significant share of income flows to agriculture and forestry. Correspondingly, in the Jakobstad region a considerable amount of wind power is necessary to achieve $100 \%$ RES production, because of its intensive industry, and here the main economic gain is for investors outside the region (capital income, Table 10). 
Table 8. Costs of energy (millions of euros, M€) in the research areas by consumption categories.

\begin{tabular}{|c|c|c|c|c|c|c|}
\hline \multirow{2}{*}{$\begin{array}{l}\text { Region } \\
\text { Municipality } \\
\text { Village }\end{array}$} & \multirow[b]{2}{*}{ Electricity } & \multirow[b]{2}{*}{ Heat } & \multicolumn{3}{|c|}{ Transport } & \multirow[b]{2}{*}{ TOTAL } \\
\hline & & & Heavy & Light & $\begin{array}{c}\text { Agri- } \\
\text { culture }\end{array}$ & \\
\hline Kaustinen & 11.6 & 14.3 & 22.2 & 21.4 & 4.9 & 74.4 \\
\hline Kaustinen & 3.6 & 4.1 & 5.9 & 5.9 & 0.97 & 20.5 \\
\hline Halsua & 0.76 & 1.2 & 1.5 & 1.6 & 0.52 & 5.8 \\
\hline Lestijarvi & 0.83 & 0.79 & 1.1 & 1.0 & 0.32 & 4.0 \\
\hline Toholampi & 2.8 & 3.1 & 4.7 & 4.1 & 1.1 & 15.8 \\
\hline Veteli & 2.1 & 3.0 & 5.0 & 4.8 & 1.1 & 16.0 \\
\hline Perho & 1.6 & 2.1 & 4.1 & 3.7 & 0.91 & 12.3 \\
\hline Perho & 0.95 & 0.81 & 2.0 & 1.8 & 0.15 & 5.7 \\
\hline Jakobstad & 86.1 & 39.1 & 43.2 & 55.5 & 5.8 & 229.8 \\
\hline Jakobstad & 61.0 & 17.8 & 12.9 & 21.3 & 0.14 & 113.1 \\
\hline Pedersore & 7.4 & 7.5 & 11.3 & 12.5 & 2.2 & 40.9 \\
\hline Kronoby & 8.3 & 5.8 & 7.7 & 7.9 & 1.7 & 31.6 \\
\hline Larsmo & 2.1 & 2.2 & 2.2 & 5.0 & 0.11 & 11.6 \\
\hline Nykarleby & 7.4 & 5.8 & 9.0 & 8.8 & 1.5 & 32.5 \\
\hline Jерuа & 1.7 & 1.7 & 3.3 & 1.7 & 0.14 & 8.6 \\
\hline Pensala & 0.27 & 0.27 & 0.31 & 0.48 & 0.13 & 1.5 \\
\hline Vörå & 4.8 & 3.3 & 7.5 & 7.9 & 2.4 & 25.9 \\
\hline Komossa & 0.07 & 0.09 & 0.13 & 0.16 & 0.10 & 0.55 \\
\hline Karijoki & 1.0 & 1.5 & 2.4 & 1.8 & 0.91 & 7.6 \\
\hline Karijoki & 0.44 & 0.77 & 1.5 & 1.2 & 0.15 & 4.1 \\
\hline Jalasjärvi & 5.6 & 7.3 & 10.7 & 9.2 & 0.97 & 33.7 \\
\hline Ilvesjoki & 0.32 & 0.46 & 0.71 & 0.84 & 0.16 & 2.5 \\
\hline
\end{tabular}

Table 9. The value of $100 \%$ self-sufficient regional RES energy production by RES energy categories in the research areas (millions of euros, M€).

\begin{tabular}{lccrr}
\hline \hline $\begin{array}{l}\text { Region } \\
\text { Municipality } \\
\text { Village }\end{array}$ & Biogas & CHP & Wind & TOTAL \\
Kaustinen & & & & \\
Kaustinen & $\mathbf{2 1 . 5}$ & $\mathbf{4 5 . 4}$ & $\mathbf{7 . 5}$ & $\mathbf{7 4 . 4}$ \\
Halsua & 4.1 & 9.2 & & 13.3 \\
Lestijarvi & 1.9 & 3.8 & & 5.7 \\
Toholampi & 1.3 & 3.0 & & 4.3 \\
Veteli & 5.6 & 10.6 & & 16.2 \\
Perho & 4.7 & 10.8 & & 15.5 \\
$\quad$ Perho & 3.8 & 8.0 & 7.5 & 19.3 \\
\hline Jakobstad & 1.1 & 1.3 & 3.3 & 5.7 \\
Jakobstad & 19.1 & 62.4 & 148.3 & $\mathbf{2 2 9 . 8}$ \\
Pedersore & 0.36 & 3.3 & 8.4 & 12.0 \\
Kronoby & 6.6 & 19.8 & 31.4 & 57.8 \\
Larsmo & 6.0 & 16.1 & 4.0 & 26.1 \\
Nykarleby & 0.32 & 3.0 & 0.31 & 3.7 \\
$\quad$ Jepua & 5.6 & 19.4 & 105.2 & 130.2 \\
$\quad$ Pensala & 1.9 & 3.7 & 3.0 & 8.6 \\
\hline Vörå & 1.5 & 9 & & 1.5 \\
$\quad$ Komossa & 7.1 & 18.8 & & 25.9 \\
\hline Karijoki & 0.39 & 0.16 & & 0.55 \\
\hline Karijoki & 3.8 & 3.8 & & 7.6 \\
\hline Jalasjärvi & 0.30 & 2.4 & 1.4 & 4.1 \\
\hline Ilvesjoki & 4.1 & 13.7 & 15.9 & 33.7 \\
\hline \hline & 0.73 & 1.7 & & 2.5 \\
\hline \hline
\end{tabular}


Table 10. The value of $100 \%$ regional RES energy self-sufficient production by field of business in the research areas (millions of euros, M€).

\begin{tabular}{|c|c|c|c|c|c|c|c|c|}
\hline $\begin{array}{l}\text { Region } \\
\text { Municipality } \\
\text { Village }\end{array}$ & $\begin{array}{c}\text { Agric. } \\
\text { Forrestry }\end{array}$ & $\begin{array}{c}\text { Other } \\
\text { industry }\end{array}$ & $\begin{array}{c}\text { Trans- } \\
\text { port }\end{array}$ & Financing & Other & Labour & Capital & TOTAL \\
\hline Kaustinen & 19.0 & 11.0 & 4.0 & 5.5 & 3.6 & 9.0 & 22.2 & 74.4 \\
\hline Kaustinen & 3.8 & 1.9 & 0.81 & 1.0 & 0.70 & 1.7 & 3.5 & 13.4 \\
\hline Halsua & 1.6 & 0.83 & 0.34 & 0.43 & 0.32 & 0.76 & 1.5 & 5.7 \\
\hline Lestijarvi & 1.2 & 0.60 & 0.26 & 0.33 & 0.22 & 0.54 & 1.1 & 4.2 \\
\hline Toholampi & 4.4 & 2.4 & 1.0 & 1.2 & 0.92 & 2.2 & 4.2 & 16.2 \\
\hline Veteli & 4.4 & 2.2 & 0.95 & 1.2 & 0.80 & 2.0 & 4.0 & 15.5 \\
\hline Perho & 3.7 & 3.1 & 0.71 & 1.3 & 0.69 & 1.9 & 8.0 & 19.3 \\
\hline Perho & 0.73 & 1.0 & 0.13 & 0.32 & 0.19 & 0.50 & 2.8 & 5.7 \\
\hline Jakobstad & 31.7 & 39.0 & 5.1 & 14.5 & 4.4 & 15.7 & 119.4 & 229.8 \\
\hline Jakobstad & 1.7 & 2.0 & 0.25 & 0.78 & 0.15 & 0.71 & 6.5 & 12.0 \\
\hline Pedersore & 9.4 & 9.5 & 1.7 & 3.8 & 1.4 & 4.5 & 27.5 & 57.7 \\
\hline Kronoby & 6.7 & 3.8 & 1.4 & 2.0 & 1.1 & 2.9 & 8.3 & 26.1 \\
\hline Larsmo & 1.2 & 0.47 & 0.23 & 0.34 & 0.09 & 0.34 & 1.1 & 3.7 \\
\hline Nykarleby & 12.9 & 23.2 & 1.6 & 7.6 & 1.7 & 7.3 & 76.0 & 130.2 \\
\hline Jерua & 1.7 & 1.4 & 0.33 & 0.58 & 0.34 & 0.88 & 3.5 & 8.6 \\
\hline Pensala & 0.13 & 0.30 & 0.05 & 0.03 & 0.20 & 0.34 & 0.40 & 1.5 \\
\hline Vörå & 7.5 & 3.6 & 1.6 & 2.1 & 1.2 & 3.2 & 6.7 & 25.9 \\
\hline Komossa & 0.09 & 0.10 & 0.03 & 0.02 & 0.06 & 0.10 & 0.15 & 0.5 \\
\hline Karijoki & 1.7 & 1.2 & 0.41 & 0.47 & 0.58 & 1.2 & 2.0 & 7.6 \\
\hline Karijoki & 1.0 & 0.60 & 0.18 & 0.33 & 0.08 & 0.33 & 1.6 & 4.1 \\
\hline Jalasjärvi & 6.2 & 5.4 & 1.1 & 2.3 & 0.86 & 2.7 & 15.1 & 33.7 \\
\hline Ilvesjoki & 0.71 & 0.35 & 0.15 & 0.20 & 0.12 & 0.31 & 0.64 & 2.5 \\
\hline
\end{tabular}

\subsection{Regional Impacts of the RegFin Model}

The estimated values of production (actual or planned turnover) of the plants in each region are presented in the first row in Tables 11-13. The RegFin model evaluation of the impacts on the regional economy and the corresponding impacts on employment for these activities are measured by regional GDP in both relative and absolute terms. The results in Tables 11 and 12 indicate that, for a partly selfsufficient raw material chain, multiplier impacts are small. In Jepua Energy Village the multipliers for GDP are positive for wind power and biogas. In Perho Energy Village, GDP multipliers are slightly negative for a partly self-sufficient raw material chain. For both Energy Villages, all RES types have positive impacts in relative terms in the case of a totally self-sufficient raw material chain. The regional economic impacts increase considerably if all intermediates can be bought from within the region.

The employment multipliers for Jakobstad and Kaustinen regions are positive, even in the case of a partly self-sufficient material chain. In the former region, values of the multipliers range from 0.02 to 0.1 , representing employment gains of 3-21 person-years. In the latter region, the corresponding ranges are 0.02 to 0.2 for multipliers and 1-15 person-years. In the case of a totally self-sufficient material chain, the employment impacts are somewhat greater. In Jakobstad region, employment multipliers are in the range $0.02-0.2$, representing 4-41 person-years. In Kaustinen region the corresponding values are 0.01-0.3 for multipliers and 5-23 person-years. CHP creates most employment in the Jakobstad region, but wind power and biogas create the most in Kaustinen region. Thus, renewable energy will create new employment, and the number of person-years created depends on the scale of the activities and differences in regional business structures 
Table 11. The scenario results from Jakobstad region: change of regional GDP and its multiplier impact caused by RES energy production in Jepua Energy Village.

\begin{tabular}{|c|c|c|c|c|}
\hline & CHP & Wind Power & Biogas & TOTAL \\
\hline Production, M€ (direct effect) & 4.9 & 1.1 & 1.5 & 7.5 \\
\hline \multicolumn{5}{|l|}{ Partly self-sufficing } \\
\hline $\begin{array}{l}\text { Regional GDP (total effect) } \\
\text { Change, \% points } \\
\text { Change, M€ }\end{array}$ & $\begin{array}{l}0.3 \\
3.8\end{array}$ & $\begin{array}{l}0.1 \\
1.4\end{array}$ & $\begin{array}{l}0.1 \\
1.9\end{array}$ & $\begin{array}{l}0.5 \\
7.1\end{array}$ \\
\hline Multiplier effect & -0.2 & 0.2 & 0.3 & -0.1 \\
\hline $\begin{array}{l}\text { Regional employment effect } \\
\text { Change, \% points } \\
\text { Change, person years }\end{array}$ & $\begin{array}{r}0.1 \\
21.3\end{array}$ & $\begin{array}{r}0.02 \\
2.5\end{array}$ & $\begin{array}{r}0.03 \\
3.9\end{array}$ & $\begin{array}{r}0.1 \\
27.7\end{array}$ \\
\hline \multicolumn{5}{|l|}{ Totally self-sufficing } \\
\hline $\begin{array}{l}\text { Regional GDP (total effect) } \\
\text { Change, \% points } \\
\text { Change, M€ }\end{array}$ & $\begin{array}{l}0.5 \\
8.6\end{array}$ & $\begin{array}{l}0.2 \\
2.5\end{array}$ & $\begin{array}{l}0.2 \\
3.3\end{array}$ & $\begin{array}{r}0.9 \\
14.3\end{array}$ \\
\hline Multiplier effect & 0.8 & 1.2 & 1.1 & 0.9 \\
\hline $\begin{array}{l}\text { Regional employment effect } \\
\text { Change, \% points } \\
\text { Change, person years }\end{array}$ & $\begin{array}{r}0.2 \\
40.9\end{array}$ & $\begin{array}{r}0.02 \\
3.5\end{array}$ & $\begin{array}{r}0.04 \\
9.2\end{array}$ & $\begin{array}{r}0.3 \\
53.6\end{array}$ \\
\hline
\end{tabular}

Table 12. The scenario results from Kaustinen region: change of regional GDP and its multiplier impact caused by RES energy production in Perho Energy Village.

\begin{tabular}{|l|c|c|c|c|}
\hline & CHP & Wind Power & Biogas & TOTAL \\
\hline Production, M€ (direct effect) & 0.4 & 4.8 & 2.9 & 8.1 \\
\hline Partly self-sufficing & & & & \\
\hline Regional GDP (total effect) & & & & \\
$\quad$ Change, \% points & 0.1 & 1.5 & 0.6 & 2.1 \\
$\quad$ Change, M€ & 0.2 & 4.6 & 1.8 & 6.6 \\
\hline Multiplier effect & -0.4 & -0.04 & -0.4 & -0.2 \\
\hline Regional employment effect & & & & \\
$\quad$ Change, \% points & 0.02 & 0.2 & 0.2 & 0.4 \\
$\quad$ Change, person years & 1.2 & 11.2 & 15.3 & 27.7 \\
\hline Totally self-sufficing & & & & \\
\hline Regional GDP (total effect) & & & & \\
$\quad$ Change, \% points & 0.3 & 2.1 & 1.3 & 3.7 \\
$\quad$ Change, M€ & 0.8 & 6.4 & 4.0 & 0.4 \\
\hline Multiplier effect & 1.1 & 0.3 & 0.4 & \\
\hline Regional employment effect & & & & 0.6 \\
$\quad$ Change, \% points & 0.01 & 0.3 & 0.3 & 50.3 \\
$\quad$ Change, person years & 5.1 & 22.6 & 22.6 & \\
\hline \hline
\end{tabular}

It is not typical in CGE analysis to disaggregate the total impact into different parts, such as direct, indirect and induced impacts. An exception has been made here, because the multiplier is a relevant indicator in this calculation, since the multiplier impact is the sum of indirect and induced impacts. The value of production is the direct impact, and the absolute change in regional GDP is the total impact. The multiplier impact in absolute terms is the corresponding total impact minus the direct impact. In relative terms the multiplier indicates how many additional euros are brought to the regional economy by a one euro increase in RES production.

The multiplier is calculated as:

Total impact / direct impact - 1 . 
Table 13. The scenario results for CHP from Jakobstad and Kaustinen regions: change of regional GDP and its multiplier impacts caused by selling a materials surplus of $25 \%$ and $50 \%$ to other regions, in Jepua and Perho villages.

\begin{tabular}{|l|r|r|}
\hline & Jepua & Perho \\
\hline Production, M€ (direct effect) & 4.9 & 0.4 \\
\hline 25\% surplus & & \\
\hline $\begin{array}{l}\text { Regional GDP (total effect) } \\
\text { Change, \% } \\
\text { Change, M€ }\end{array}$ & 0.6 & 0.3 \\
\hline Multiplier effect & 10.2 & 0.9 \\
\hline Regional employment effect & 1.1 & 1.3 \\
$\quad$ Change, \% & & \\
$\quad$ Change, person years & 0.2 & 0.1 \\
\hline 50\% surplus & 53.7 & 6.4 \\
\hline Regional GDP (total effect) & & \\
$\quad$ Change, \% & & 0.3 \\
$\quad$ Change, M€ & 0.7 & 1.1 \\
\hline Multiplier effect & 12.7 & 1.8 \\
\hline Regional employment effect & 1.6 & 0.1 \\
$\quad$ Change, \% & & 7.7 \\
\hline Change, person years & 6.3 & \\
\hline \hline
\end{tabular}

For instance, for Jepua Energy Village, using the impact estimate for a totally selfsufficient raw material chain and including wind power, we obtain a value for the regional GDP multiplier of $2.5 / 1.1-1=1.2$, given the rounding of numbers as for Table 12.

There are some negative multiplier values in cases of partly self-sufficient raw material chains for CHP (Table 11) or for CHP and biogas (Table 12). The multipliers are negative because the total impact in absolute terms is less than the corresponding direct impact. This indicates that the additional turnover of one euro for these renewables contributes less than one euro to the regional GDP in absolute terms. This results in a monetary flow to outside the region. It represents a trade deficit and loss of welfare.

The production of CHP and biogas creates an increase in regional GDP and employment that boosts local welfare, but not all additional money will be spent on consumer goods and services available within the region. Domestic and foreign imports to a region represent expenditure for the region, and their value is deducted in the regional GDP calculation. A negative regional GDP multiplier means that too large a share of the additional income is used in consumption of imports from other regions or from abroad.

For Jakobstad region, benefits from using only local raw materials, repair and maintenance services and other similar intermediates, increase the positive regional impacts considerably. The multipliers for Jepua village range from 0.8 to 1.2 in the case of a totally self-sufficient material chain. For an additional production of renewables worth one euro, the activity brings an additional regional GDP of 80 cents to 1.2 euros. 
The argumentation for the Kaustinen region is the same. Wind power is, in relative terms, the most efficient in creating welfare in the Jakobstad region, and CHP is the most efficient in the Kaustinen region. In the case of a partly self-sufficient raw material chain, CHP and biogas plants would cause money flows to outside the Kaustinen region which are somewhat larger than for CHP in the Jakobstad region. The situation is neutral for wind power. The multiplier impacts improve in the case of a totally self-sufficient raw material chain. All multiplier values are then positive in the range from 0.3 to 1.1. For an additional production of renewables worth one euro the activity contributes an additional 30 cents to 1.1 euros to the regional GDP. The efficient use of local raw materials, repair and maintenance services and other similar intermediates increases the positive regional impacts.

Our estimates also indicate that if the region can produce a surplus with respect to its raw material chain, then it is able to sell raw materials, such as wood chips and other intermediates, to other regions. Table 13 reports this finding for CHP in both Energy Villages. Our results for wind power and biogas did not imply a similar development. The values of the regional GDP multipliers increase with the selling of material surplus. The key contributory factor is increased income from domestic export. The argumentation is the same for Perho village, but the increases in the values of regional GDP multipliers are somewhat higher than in Jepua.

\section{Discussion}

\subsection{Research design}

There has been much discussion on the regional economic impacts of the use of RES. The added value for regions, via factors such as direct earnings, growth in purchasing power, decrease in costs, increased employment and increased tax revenue, has been previously studied (Bentzen et al., 1997; Hoffmann, 2009; Sastresa et al., 2010; Trink et al., 2010). The scientific estimates include costs and employment within some branches, technologies and their value chains on different regional scales, content and approaches (Ortega et al., 2015; Connolly et al., 2016; Markandya et al., 2017; Többen, 2017). The methodology is not established, and there are only a few analyses that cover the potential regional economic impacts of RES self-sufficiency.

This paper aims at shedding light on this important issue by presenting the results from a study of two regions, which include municipalities and Energy Villages within them, and three other municipalities and Energy Villages in the province of Western Finland. The basic material consists of regional data on energy demand (heating, electricity, transport fuel and agricultural machinery), RES potential (bioenergy and wind power capacity from planned and already constructed plants) and energy balances.

The regional economic impacts were estimated in two ways. Firstly, the direct economic value and its division into business categories corresponding to the different actors within value chains of each method, was calculated using average actual prices and the estimated consumption of energy. Secondly, the regional GDP (gross domestic product) and employment impact values were calculated using the CGE model RegFin, where the renewable energy sectors (CHP, wind and biogas) were segregated as separate industries in the database. This enabled detailed analysis of the impacts of each energy form. 
Both these methods were based on the energy balances of each sub-area, and an imaginary allocation of RES by production method, i.e., biogas, CHP combustion and, whenever necessary, supplementary production via wind power. This simplification was made because the money flows through value chains are well understood for these technologies, and these forms of RES will be the most relevant with respect to future practical implementation in the target areas.

\subsection{Renewable energy self-sufficiency and economy}

The basic data show the same potential for self-sufficiency in energy management via RES, especially in rural regions, as has been reported several times previously, (e.g., reviewed by Peura and Hyttinen, 2011; Peura, 2013a; Connolly et al., 2017). In many cases, bioenergy alone would be sufficient to cover all the energy demand in sparsely populated rural areas. For more industrialized and densely populated rural areas, other RES, e.g., wind power will be needed if self-sufficiency is to be achieved, e.g., in the Jakobstad region. However, all regions in this study could easily produce their energy via RES, and even sell energy outwards. This also means that the calculations concerning regional economies given here are highly justified and realistic, even when considering the potential and the implementation in practical terms.

The direct annual economic value of the production of energy is more than $€ 74 \mathrm{~m}$ in the Kaustinen region and $€ 230 \mathrm{~m}$ in the Jakobstad region, representing nearly $€ 4,860$ per capita. Although energy is already partly produced via RES at present from within the regions, especially for heating, it is still true that most of this money will flow out of the regions. Surprisingly, a nearly equal amount of money is spent on energy per capita in these two regions, although their business structures are different.

The presupposition is that by creating regional self-sufficiency, all the money could be kept within the region and its RES-based value chains. This could be most easily achieved by promoting the use of bioenergy, since, e.g., wind power is usually produced by large, often international organizations, that collect the largest benefits and export the profits from the regions. This can clearly be seen in the results showing the division of money flows along the value chain to different branches. For instance, in the Kaustinen region, agriculture and forestry would obtain a substantial new source of income (Table 10), while in the Jakobstad region the largest share of money would flow to wind power producers (capital, Table 10).

\subsection{RegFin modelling}

The RegFin results show that the impacts were markedly different, depending on what was assumed about the self-sufficiency in raw materials. The multiplier impacts were greater for the Jakobstad region than for the Kaustinen region in the case of a partially self-sufficient (possible trade to and from outside the region) raw material chain. In Jakobstad, a total of 10 cents of every euro from RES production flowed outside the region. This ratio was lower for Kaustinen, with almost 20 cents of every euro flowing outside the region. In the case of a fully self-sufficient (all transactions within the region) raw material chain, the multiplier impacts were positive for both regions. Jakobstad seemed to benefit from RES production more than Kaustinen. In the Jakobstad region, every euro spent on RES production produced an additional 90 cents in other areas of the regional economy. For the Kaustinen region this ratio was lower, at 40 cents.

When production is based on intermediates supplied by the region, the multiplier impact increases significantly. This implies the importance of carrying out 
economic transactions within the region as much as possible: the more purchases that take place within the region, the more the region benefits. Furthermore, the business structure of the region plays an important role. The business structures of Jakobstad and Kaustinen regions are very different from each other. In addition, the regional economy of Jakobstad region is over five times greater than that of Kaustinen.

\subsection{Summarising and analysing remarks}

In summary, the results show that RES production, based on a self-sufficient raw material chain, has positive impacts on regional economies, and that the benefits are related to the business structure of each region. This study, therefore, supports the general assumption that RES production supports regional economies. The results are in accordance with previous findings about the economic impacts of the use of RES.

However, there are also some contrary observations. On a larger scale, for instance, simulation of regional economic impacts of bioenergy in Finland showed that the use of bioenergy decreased GDP and employment, though still helping to achieve emissions goals (Simola and Kola, 2010). The negative impacts were due to increased energy costs, as the increase in bioenergy was deducted from the import of fossil energy. The results also displayed regional differences; one of the counties was the only clear winner, because it could export bioenergy.

A recent study on CHP, wind energy and biogas (Prime Minister's Office, 2017) indicated that if the full potential of RES were used, this would create 5,640 new job opportunities in Finland. The additional GDP would be $€ 1,800 \mathrm{~m}$. In a research scenario where renewables replaced all fossil energy, an economic loss was observed. The net impact would be $-0.4 \%$ in both national employment and GDP. In Germany, the implementation of RES for producing electricity has resulted in only small economic benefits, (e.g., Többen, 2017), and "the prospects for employment and welfare gains are quite limited and hinge crucially on the level of the subsidy rate and the financing mechanism..." (Böhringer et al., 2013).

Therefore, it is also important to take into account the fact that economic gain is not the only driver for implementing SE - other reasons, such as climate protection, (e.g., Többen, 2017) and exhaustion of fossil fuels, will force this transition to take place, together with a complete reformation of the entire energy sector (e.g., Jefferson, 2008). For example, driving factors are strongest for policies aiming at implementing renewable energy regionally (Lutz et al., 2017).

In the Smart Energy Europe scenario (Connolly et al., 2016) the transition would result in some 10 million new European jobs, and even though costs are greater than for the conventional system, most of the costs would be converted from imported fossil fuel to local investments. While this kind of replacement will naturally cause losses in the fossil value chain, it will also result in an overall gain for the EU economy - and in terms of the studied Finnish regions, it will offer substantial benefits to regional economies. This is well in line with the observations from the province of Eastern Finland (Lehtonen and Okkonen, 2016), also underlining the importance of a regional approach. RES implementation will be especially beneficial for more peripheral regions.

The total impact always depends on scale: Capital-intensive large-scale wind power, for instance, provides more jobs abroad within large manufacturing organizations, rather than in the target areas (see Cai et al., 2017). For villages and small regions it is logical to see significant positive impacts, because 
implementation of RES usually means mobilization of unused but readily available resources, a reduction in outward money flow for purchasing fossil fuels and more efficient use of existing machinery, e.g., in forestry and agriculture, especially in the case of utilizing bioenergy. This is clearly seen in the results of the present research.

\section{Conclusions and Recommendations for Future Research}

The conclusions drawn are as follows.

- The studied regions can be RES self-sufficient, and can even produce an excess.

- Renewable energy and the utilization of existing but presently unused resources, can potentially play an important role in improving regional economies, especially in rural regions.

- The impacts have a connection to business structures and to the overall size of the regional economy.

- The contrary findings imply that scale is important: rural regions can create employment and benefit by circulating money within the region, while nationally the loss of jobs in the established fossil fuel-based economy leads to negative impacts in this respect.

The research findings concerning the regional economic impacts of the use of RES are still too sparse for comprehensive conclusions and generalizations. Results to date are promising and motivating, for considering more widespread use of RES in practice. Scientifically, more evidence will be necessary from future research, especially with regard to the following aspects.

- Clarification and analyses for establishing a common methodology.

- More precise research, in terms of business branches, geographical context and volume of studies. 


\section{Acknowledgements}

This paper presents the results from the project "Regional impacts of sustainable energy", funded by the Rural Policy Committee (Ministry of Agriculture and Forestry and Ministry of Employment and the Economy, Finland). The Levón Institute (University of Vaasa) coordinated the project, and the Ruralia Institute (University of Helsinki) was a partner. The initial data concerning regional energy balances were provided by the Energy Village project, funded by the European Regional Development Fund.

\section{List of abbreviations}

\begin{tabular}{ll} 
CEO & Chief Executive Officer \\
CGE & Computable General Equilibrium, modelling method \\
CHP & Combined Heat and Power (electricity) production \\
GDP & Gross Domestic Product \\
GWh, MWh, kWh \\
\multicolumn{2}{c}{ Gigawatt hours, Megawatt hours, Kilowatt hours } \\
RES & Renewable Energy Sources \\
RUE & Rational Use of Energy \\
SE & Sustainable Energy \\
TS; VS & Total Solids; Volatile Solids
\end{tabular}

\section{References}

Alakangas, E. (2000). Suomessa käytettävien polttoaineiden ominaisuuksia. (In Finnish; Characteristics of fuels used in Finland). Notice 2045, VTT, Espoo.

Bentzen J., Smith V. and Dilling-Hansen, M. (1997). "Regional income effects and renewable fuels. Increased usage of renewable energy sources in Danish rural areas and its impact on regional incomes." Energy Policy 25: 185-191.

Blanco, M.I. and Rodrigues, G. (2009). "Direct employment in the wind energy sector: An EU study." Energy Policy 37: 2847-2857. http://dx.doi.org/10.1016/j.enpol.2009.02.049.

Blarke, M.B. (2008). From dusk till dawn. An essay about how the climate crisis has come to define sustainable energy in the context of the Danish experiment, Aalborg: Aalborg University.

Böhringer, C., Keller, A. and van der Werf, E. (2013). "Are green hopes too rosy? Employment and welfare impacts of renewable energy promotion." Energy Economics 36: 277-285. https://doi.org/10.1016/j.eneco.2012.08.029.

Cai, M., Cusumano, N., Lorenzoni, A. and Pontoni, F. (2017). "A comprehensive expost assessment of RES deployment in Italy: Jobs, value added and import leakages." Energy Policy 110:234-245. https://doi.org/10.1016/j.enpol.2017.08.013.

Ceciliano, R. (2010). "WBA's report shows: The global potential of sustainable bioenergy is enough to meet the world's total energy needs." Bioenergy 3: 4-5. 
Chichilnisky, G. (2011). "What is sustainability?" International Journal of Sustainable Economy 3: 125-140. http://dx.doi.org/10.1504/IJSE.2011.039437.

Connolly, D., Lund, H. and Mathiesen, B.V. (2016). "Smart Energy Europe: The technical and economic impact of one potential $100 \%$ renewable energy scenario for the European Union." Renewable and Sustainable Energy Reviews 60: 1634-1653. https://doi.org/10.1016/j.rser.2016.02.025.

Dalton, G.J. and Lewis, T. (2011). "Metrics for measuring job creation by renewable energy technologies, using Ireland as a case study." Renewable and Sustainable Energy Reviews 15: 2123-2133. http://dx.doi.org/10.1016/j.rser.2011.01.015.

Dixon, P.B. and Jorgensen, D. (Eds.;2012). Handbook of Computable General Equilibrium Modeling. Volumes $1 \mathrm{~A}$ and $1 \mathrm{~B} .1^{\text {st }}$ edition. North Holland.

Doukas, H., Mannsbart, W., Patlitzianas, K.D., Psarras, J., Ragwitz, M. and Schlomann, B. (2007). "A methodology for validating the renewable energy data in EU." Renewable Energy 32: 1981-1998. http://dx.doi.org/10.1016/j.renene.2006.10.007.

Goldemberg, J. (2007). "Ethanol for a Sustainable Energy Future." Science 315: 808810. http://dx.doi.org/10.1126/science.1137013.

Finbio 2005. Energy units and transforming coefficients. www.finbioenergy.fi/.

Fischer, G. and Schrattenholzer, L. (2001). "Global biomass potentials through 2050." Biomass and Bioenergy 20: 151-159.

Haas, R., Watson, J. and Eichhammer, W. (2008). "Transitions to sustainable energy systems - Introduction to the energy policy special issue." Energy Policy 36 : 4009-4011. http://dx.doi.org/10.1016/j.enpol.2008.06.015.

Hakala, K., Kontturi, M. and Pahkala, K. (2009). "Field biomass as global energy source." Agricultural and food science 18: 347-365.

Hillebrand, B., Buttermann, H.G., Behringer, J.M. and Bleuel, M. (2006). "The expansion of renewable energies and employment effects in Germany." Energy Policy 34: 3484-3494. http://dx.doi.org/10.1016/j.enpol.2005.06.017.

Hoffmann, D. (2009). "Creation of regional added value by regional bioenergy resources." Renewable and Sustainable Energy Reviews 13: 2419-2429. http://dx.doi.org/10.1016/j.rser.2009.04.001.

IUCN (1980). World Conservation Strategy: living resource conservation for sustainable development, IUCN; UNEP; WWF; FAO; Unesco.

Jefferson, M. (2008). "Accelerating the transition to sustainable energy systems." Energy Policy 36: 4116-4125. http://dx.doi.org/10.1016/j.enpol.2008.06.020.

Johnston, P., Everard, M., Santillo, D. and Robért, K.-H. (2007). "Reclaiming the Definition of Sustainability." Environmental science and pollution research international 14: 60-66. http://dx.doi.org/10.1065/espr2007.01.375.

Ladanai, S. and Vinterbäck, J. (2009). Global Potential of Sustainable Biomass for Energy. Swedish University of Agricultural Sciences, Report 013. Uppsala. 29 pp.

Lehr, U., Nitsch, J., Kratzat, M., Lutz, C. and Edler, D. (2008). "Renewable energy and employment in Germany." Energy Policy 36: 108-117. http://dx.doi.org/10.1016/j.enpol.2007.09.004.

Lehtonen, O. and Okkonen, L. (2016). " Socio-economic impacts of a local 
bioenergy-based development strategy - The case of Pielinen Karelia, Finland." Renewable Energy 85: 610-619. https://doi.org/10.1016/j.renene.2015.07.006.

Lutz, L.M., Fischer, L-B., Newig, J and Lang, D.J. (2017). "Driving factors for the regional implementation of renewable energy - A multiple case study on the German energy transition." Energy Policy 105: 136-147. https://doi.org/10.1016/j.enpol.2017.02.019.

Magnani, N. and Vaona, A. (2013). "Regional spillover effects of renewable energy generation in Italy." Energy Policy 56: 663-671. https://doi.org/10.1016/j.enpol.2013.01.032.

Markandya, A., Halsnaes, K., Mason, P. and Olhoff, A. (2002). A Conceptual Framework for Analysing Climate Change in the Context of Sustainable Development, In: Markandya, A. and Halsnaes, K. (Eds.), Climate change and sustainable development: prospects for developing countries, London: Earthscan, pp. 15-48.

Markandya, A., Arto, I., Gonzáles-Equino, M. and Román, M.V. (2017). “Towards a green energy economy? Tracking the employment effects of low-carbon technologies in the European Union." Applied Energy 179: 1342-1350. https://doi.org/10.1016/j.apenergy.2016.02.122.

Masini, A. and Menichetti, E. 2012). "The impact of behavioural factors in the renewable energy investment decision making process: Conceptual framework and empirical findings." Energy Policy 40: 28-38. http://dx.doi.org/10.1016/j.enpol.2010.06.062.

McCormick, K. and Kåberger, T. (2007). "Key barriers for bioenergy in Europe: Economic conditions, know-how and institutional capacity, and supply chain coordination." Biomass and Bioenergy 31: 443-452. https://doi.org/10.1016/j.biombioe.2007.01.008.

Moreno, B. and López, A.J. (2008). "The effect of renewable energy on employment. The case of Asturias (Spain)." Renewable and Sustainable Energy Reviews 12: 732-751. http://dx.doi.org/10.1016/j.rser.2006.10.011.

Moriarty, P. and D. Honnery, D. (2009). "What energy levels can the Earth sustain?" Energy Policy 37: 2469-2474. http://dx.doi.org/10.1016/jenpol.2009.03.006.

Openshaw, K. (2010). "Biomass energy: Employment generation and its contribution to poverty alleviation." Biomass and bioenergy 34: 365-378. http://dx.doi.org/10.1016/j.biombioe.2009.11.008.

Ortega, M., del Río, P., Ruiz, P. and Thiel, C. (2015). "Employment effects of renewable electricity deployment. A novel methodology." Energy 91: 940-951. https://doi.org/10.1016/j.energy.2015.08.061.

Peura, P. and Hyttinen, T. (2011). "The potential and economics of bioenergy in Finland." Journal of Cleaner Production 19 (9-10) 927-945. http://dx.doi.org/10.1016/j.jclepro.2011.02.009.

Peura, P. (2013a). "From Malthus to Sustainable Energy - Theoretical orientations to reforming the energy sector." Renewable and Sustainable Energy Reviews 19 (C) 309-327. http://dx.doi.org/10.1016/j.rser.2012.11.025.

Peura, P. (2013b). From Unlimited Growth to Sustainable Energy. The origin of operational patterns by means of social selection. Acta Wasaensia 279. Doctoral 
dissertation.

Peura, P., Kuittinen, H., Knuckey, L., Goodall, L. and Dinya, L., (2014). "Implementing Sustainable Energy - Four case studies." International Journal of Sustainable Economy 6 (1): 19-44. http://dx.doi.org/10.1504/IJSE.2014.058516.

Prime Minister's Office (2017). Opportunities and limitations of distributed energy. Publications of the Government's analysis, assessment and research activities 5.

Ragwitz M., Schleich J., Huber C., Resch G., Faber T., Voogt M., Coenraads R., Cleijne, H. and Bodo, P. (2005). Analyses of the EU renewable energy sources' evolution up to 2020 (FORRES 2020), Stuttgart: Fraunhofer IRB Verlag.

Reini, K., Törmä, H., Männistö, T., Peura, P., Kannonlahti, J., Hyttinen, T. and Haapanen, A. (2014). Uusiutuvat energian lähteet ja hajautetun energian tuotannon aluetaloudellinen vaikuttavuus Pietarsaaren ja Kaustisen seutukunnissa. (In Finnish; Renewable energy sopurces and the regionasl economic effects of distributed production of energi in Jakobstad and Kaustinen regions). Reports 115, University of Helsinki, Ruralia Institute. Available from http://www.helsinki.fi/ruralia/julkaisut/pdf/Raportteja115.pdf.

Resch, G., Held, A., Faber, T., Panzer, C., Toro, F. and Haas, R. (2008). "Potentials and prospects for renewable energies at global scale." Energy Policy 36: 40484056. http://dx.doi.org/10.1016/j.enpol.2008.06.029.

del Río, P. and M. Burguillo, M. (2009). "An empirical analysis of the impact of renewable energy deployment on local sustainability." Renewable and Sustainable Energy Reviews 13: 1314-1325. http://dx.doi.org/10.1016/j.rser.2008.08.001.

Rutherford T.F. and Törmä H. (2010). "Efficiency of Fiscal Measures in Preventing Out Migration from North-Finland." Regional Studies 44 (4): 465-475. Available from http://www.helsinki.fi/ruralia/research/regfin.htm.

Sastresa, E.L., Usón, A.A., Bribián, I.Z. and Scarpellini, S. (2010). "Local impact of renewables on employment: Assessment methodology and case study." Renewable and Sustainable Energy Reviews 14: 679-690. http://dx.doi.org/10.1016/j.rser.2009.10.017.

Simola, A. and Kola, J. (Eds.; 2010). Bioenergian tuotannon aluetaloudelliset vaikutukset Suomessa. (In Finnish; The regional economic effects of bioenergy). University of Helsinki, Departmetn of Economy, Publication Nr 49, Agricultural Economy.

Smeets, E.M.W. and Faaij, A.P (2007). "Bioenergy potentials from forestry in 2050'. "Climatic Change 81: 353-390. http://dx.doi.org/10.1007/s10584-006-9163-x.

Smeets, E.M.W., Faaij, A.P.C., Lewandowski, I.M. and Turkenburg, W.C. 2007. "A bottom-up assessment and review of global bio-energy potentials to 2050." Progress in Energy and Combustion Science 33: 56-106.

Thornley, P., Rogers, J. and Huang, Y. (2008). "Quantification of employment from biomass power plants." Renewable Energy 33: 1922-1927. http://dx.doi.org/10.1016/j.renene.2007.11.011.

Trink T., Schmid C., Schinko T., Steininger K.W., Loibnegger T., Kettner IC., Pack A. and Töglhofer C. 2010. "Regional economic impacts of biomass based energy service use: A comparison across crops and technologies for East Styria, Austria." Energy policy 38: 5912- 5926. 
Turunen, T. (1999). Maatalousjätteiden termofiilinen biometanointi ja biometanoidun jätteen jatkojalostus. (In Finnish; Thermophilic biomethanisation of agricultural waste and further refining of the process waste from biomethanisation). Pro gradu thesis, Bio and environmental sciences, University of Jyväskylä.

Többen, J. (2017). "Regional Net Impacts and Social Distribution Effects of Promoting Renewable Energies in Germany." Ecological Economics 135: 195208. https://doi.org/10.1016/j.ecolecon.2017.01.010.

Törmä, H. (2008). "Do Small Towns Development Projects Matter, and Can CGE Help?" Journal of Spatial Economic Analysis 3 (2): 247-268. Available from http://www.helsinki.fi/ruralia/research/regfin.htm.

Törmä, H. and Zawalinska, K. (2010). Methodological description of the CGERegEU model. FP7 CAPRI-RD project, Deliverable 3.2.2. Available from http://www.ilr1.uni-bonn.de/agpo/rsrch/capri-rd/del.htm.

Törmä, H. and Zawalinska, K. (2011). Final documentation of the CGERegEU+ model. FP7 CAPRI-RD project, Deliverable 3.2.3. Available from http://www.ilr1.uni-bonn.de/agpo/rsrch/capri-rd/del.htm.

Törmä H., Zawalinska K., Blanco-Fonseca M., Ferrari E. and Jansson T. (2010). Regional CGE model layout with a focus on integration with the partial equilibrium models and modelling of RD measures. FP7 CAPRI-RD project, CAPRI-RD Deliverable 3.2.1. Available from http://www.ilr1.uni-bonn.de/agpo/rsrch/capri-rd/del.htm

Uusi-Penttilä, P. (2004). Biokaasun liikennekäyttö Jyväskylän seudulla. (In Finnish; Traffic use of biogas in Jyväskylä Region). Jyväskylä: Jyväskylä Science Park.

Verbruggen, A., Fischedick, M., Moomaw, W., Weir, T., Nadaï, A, Nilsson, L.J., Nyboer, J. and Sathaye, J. (2010). "Renewable energy costs, potentials, barriers: Conceptual issues." Energy Policy 38: 850-861. http://dx.doi.org/10.1016/j.enpol.2009.10.036.

WCED (1987). Our Common Future. United Nations World Commission on Environment and Development Report. 
Appendix 1. Jepua and Perho energy villages.

Jepua Energy Village (Scale: $\mathrm{km}$ ).

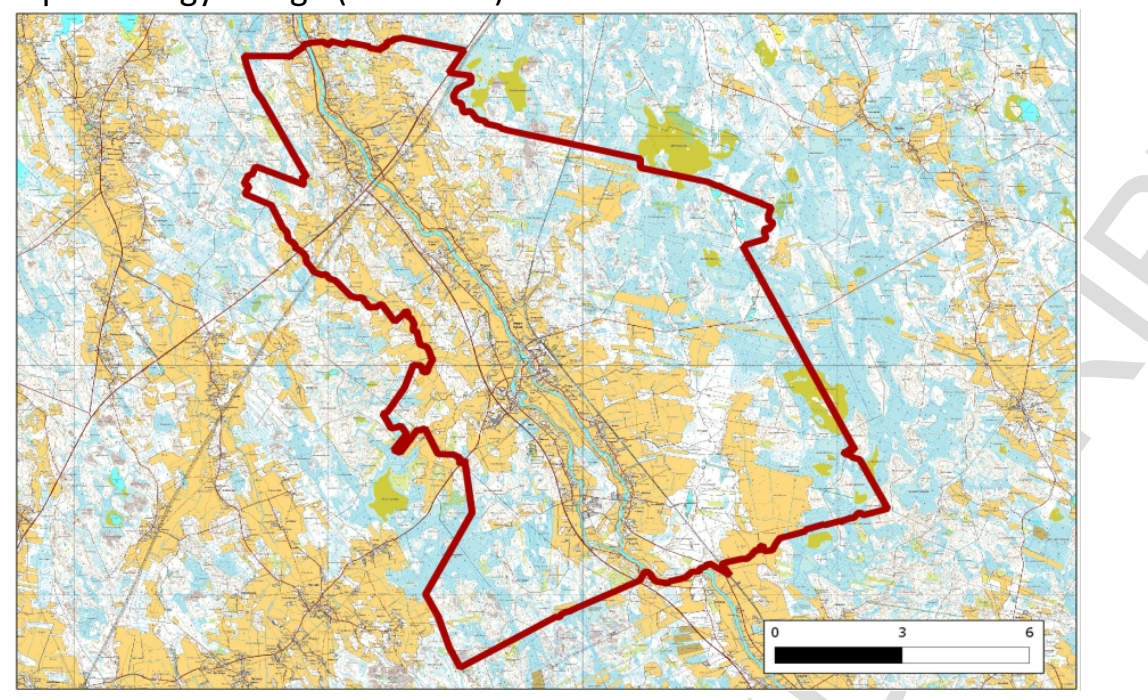

Perho Energy Village (Scale: km).

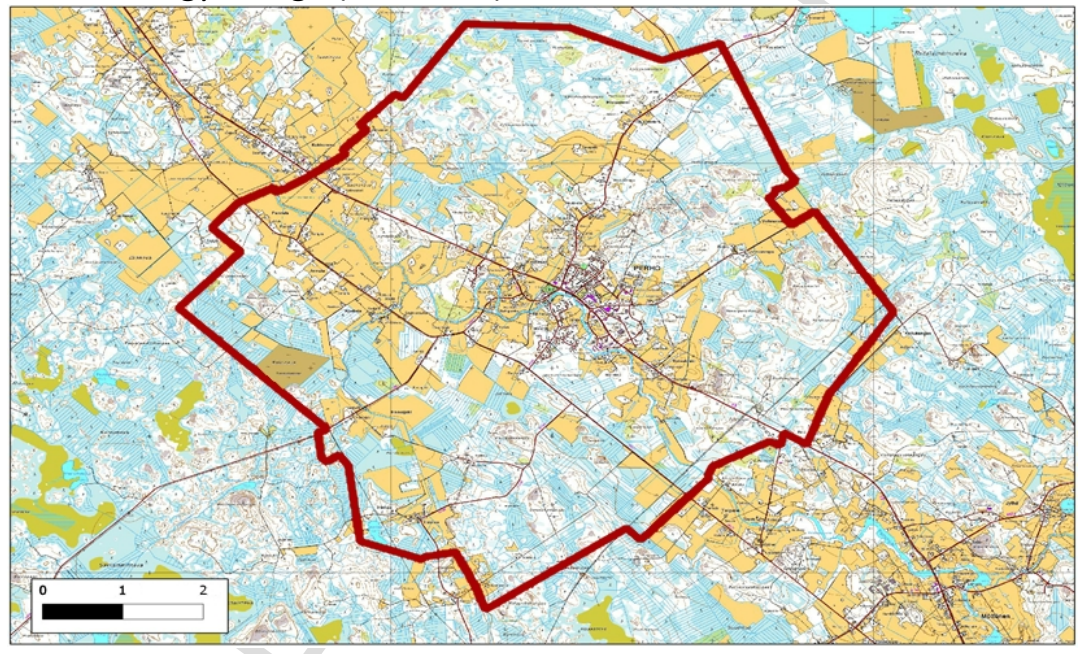




\section{Appendix 2. The Structure of the CGE RegFin Model}

The following figure shows how the regional economy is assumed to function.

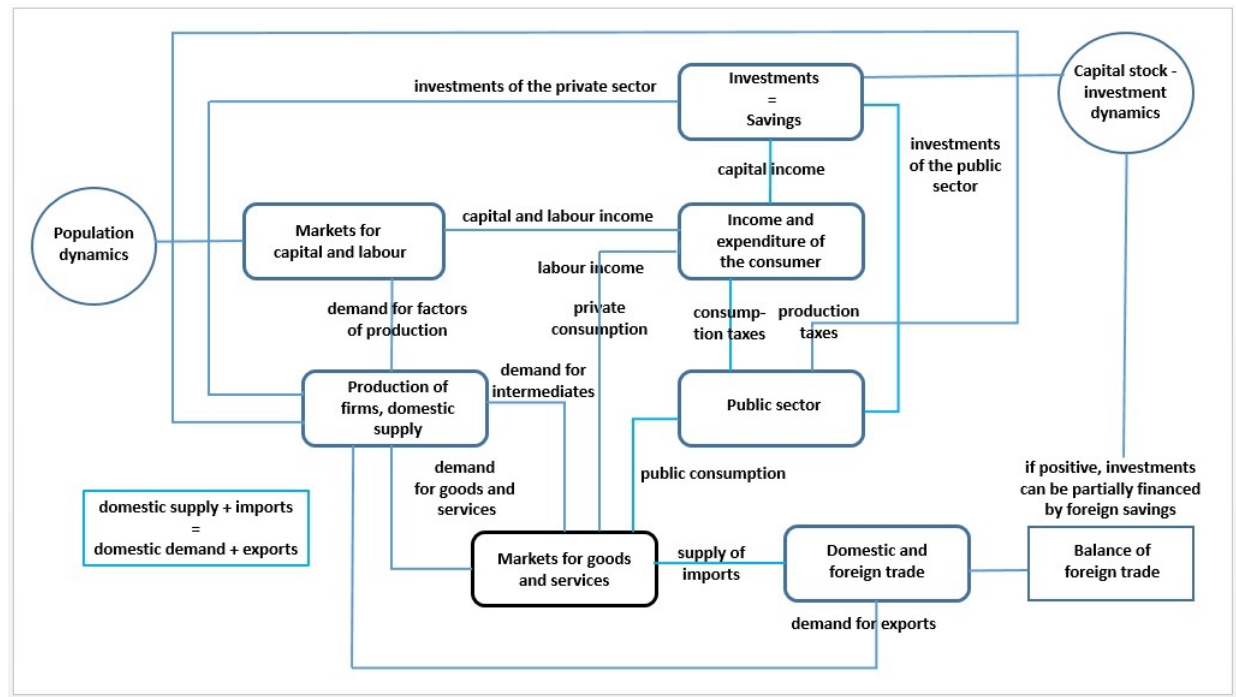

The CGE RegFin multisectoral and inter-regional simulation model takes into account, in addition to production and income, the impacts from relative prices, non-linear decision making of the actors (households, firms, investors, etc.) and resource constraints, such as the adequacy of capital and labour. It is assumed that "everything affects everything" in the economy. Furthermore, it is essential that the economy adjusts by changing relative prices after a change in economic conditions. As a multisectoral model, it can be applied to many research topics. The quantitative assessment of policy, projects and value chains for a multitude of phenomena is therefore possible. The model illustrates markets for both goods and services, and markets for factors of production. Each sector produces goods and services using two inputs: capital (for instance buildings, machines, instruments, means of transport, etc.) and labour. The land input can be disaggregated from capital according to the character of the research question. The key assumption is that there is competition between inputs, intermediate and final goods and services. Domestic and foreign goods and services compete in a setting of supply and demand. Inputs, intermediates, and goods and services are imperfect substitutes in their markets.

Private consumption is based on labour income of the households and public consumption on production and consumption of taxes in net terms. The production is sold to firms, consumers and the public sector of the region, via domestic trade to the other regions of the country and via foreign trade to other countries. Production also requires domestic and foreign imports, such as intermediate and final goods and services. Investments flow to those sectors that offer highest returns to capital. Capital incomes of firms, as well as the potential surplus from foreign trade or domestic and foreign savings, finance the investments. Demographic information for the population is recorded as part of the database of the model. Immigration and changes in population result from differences in the unemployment rate between the region and the whole country. If the unemployment rate differential increases in favour of a region, the population of that region grows, as immigration increases. Finally, in an 
equilibrium model, the sum of domestic supply and imports must be equal to the sum of domestic demand and exports.

The regional database of RegFin is based on official numbers from Statistics Finland. The main data sources are national and regional accounts. Additional data describing changes in economic conditions were collected from research and other documents, other statistics and from experts. The regional concept can be NUTS 1 (the whole of Finland), NUTS 2 (the five greater regions) or NUTS 3 (19 regions). The 19 regions can be disaggregated into several subregions. Aggregation of sectors and regions is also possible. A new sector can be separated from the main sector provided there is enough information.

The Classification of Territorial Units for Statistics (NUTS) is a geocode standard for referencing the subdivisions of countries for statistical purposes. The standard is developed and regulated by the European Union, and thus only covers the member states of the EU in detail. The Classification of Territorial Units for Statistics is instrumental in the European Union's Structural Fund delivery mechanisms, for locating areas where goods and services subject to European public procurement legislation are to be delivered.

The CGE RegFin regional simulation model is implemented and solved via Euler or Gragg algorithms in the GEMPACK software. 